\title{
Social Media Might Bring About Social Revolution in Pakistan
}

\author{
Masood Ahmed \\ Research Scholar, \\ Sindh Madressatul Islam University \\ Karachi-Pakistan \\ Masoodahmed.khan@fuuast.edu.pk \\ Dr. Noreen Aleem \\ Assistant professor \\ Sindh Madressatul Islam University \\ Karachi - Pakistan \\ noreen.aleem@smiu.edu.pk \\ Huma Nisar Khan \\ Lecturer, \\ Federal Urdu University, Karachi-Pakistan \\ h.nisar@fuuast.edu.pk
}

\begin{abstract}
This study strives to explain the great potential of revolution in Pakistani Society. We have taken into account the previous historical and modern successful revolution of the world to analyze the root cause of its success that can be associated with the potential of Pakistani people at large. Moreover, literature signifies, "How does a revolution take place?" that enables us to find our objectives. The Qualitative Research Methodology and "Hermeneutic Approach" are adapted to draw out the assumption and to understand the Psyche of Pakistani Society. According to the finding, a revolution in Pakistan might be possible and activated in future, as the present political scenario has ignited the feeling of being subjects of political class of king families. Regardless of many differences in political and religious sentiments, the Pakistani people are cathartic in nature and react emotionally and aggressively on any incidence of human injustice and tyranny. As we have seen in the past at
\end{abstract}


different sentimental issues, like agitation against ten year Ayub Era, agitation against Bhutto regime by National Alliance and in former East Pakistan as Bangladesh Revolution and above all, the successful active role of social media on all such injustices and tyrannical incidences in society. All these phenomena lead to a revolution in future to come in Pakistan.

Keywords; Revolution, sentiments, political class, society, media,

\section{INTRODUCTION}

In a philosophical sense, a revolution is a sudden and deliberate change after long term public inflictions from one form of government to another. Revolution comes in many ways, often sharing similar characteristics. Rebellious leaders, Mass anger shared state crisis of motivation. Such factors have all served to cause some of the most radical changes in history. The bourgeoisie played a key role in one of the earliest movements in modern history in the early revolution. In 1783, American colonists under Great Britain's control fought a war for their independence. Frustration among the masses also plays a critical role in social upheaval and revolt when a large percentage of a population feels seriously disconnected deprived of their political, economy and institution rights. The people of France ultimately initiated their own revolt. French civilization was gradually expelled and replaced by an empire of the monarchy. Similarly, people stood up against Ayub Era, and against Zulfiqar Ali Bhuto in Pakistan, and mutiny in Bangla Desh (the then East Pakistan) are the precedence of Pakistani Society that shows the power of reaction that might rise to the occasion.

\section{REVOLUTION}

Revolution starts when you say no to those who pretend to have control over you, and revolution comes to an end when you embrace a new status quo, new normal weather which is a change.

There are mammoth details about the causes of a revolt, but there's one common cause, that is the frustration which germinates underneath surface 


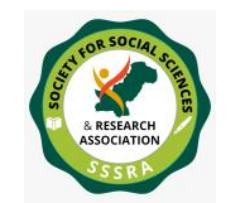

of social structure. It is a sort of storm that cultivates in people's minds, just waiting to get unleashed. The problem is the unleashing the storm, is much easier than getting people to decide on what is to come next. The characteristic of a successful movement for revolution might be possible: A movement is successful only if it starts with an idea and a magnetic leadership that must be powerful enough to take roots in the population's minds to encourage and motivate the people to spread it out. In times of great need and unity, it is possible for a diverse and divided population to create a social clique and coalition around an idea and the leadership. Intrinsically, the idea of target must meet the following three conditions. It must express a strong and established common interest to people at large that will enable the people to gather to work synchronizing. The need for reconciliation, even though this reconciliation is temporary, must be clear to all stakeholders and must be followed by a sense of urgency that impels people in their nexus to reach out to others and spread the idea (Sharp, 2012).

This is where we destroy the network of values that maintains their dominance this is where we systematically erode their aura of authority at their illusion of legitimacy. It can take several forms, and at the same time several approaches can be used, the aim of strategic non-compliance is to disrupt the chain of obedience for as long as possible and publicize the disruption on as broad a scale as possible and record the resulting police and/or military violence and to spread videos far and wide. The purpose of this is, to damage the image of the ruling party.

For power is all about image once the image begins to break down, inspiring others to disobey. Once this attracts the contagion, it is like a tidal wave, a force of nature. This is all about critical mass reading. When the people have built the momentum, necessary to take out the monopoly on violence from the hands of the current regime, such a transition can be relatively peaceful in the best of circumstances. But this is only possible when a substantial portion of the police and military have taken people's side. The police and the military are the state's security arm and without them the power that we have absolutely no control. (Sharp, 2012).

\section{THE ROLE OF COLLECTIVE BEHAVIOR AS INITIAL STAGE OF REVOLUTION}


According to McPhail (1991), an inter-actionist and socialist proposed a Perspective of Assembling to understand 'Collective Behavior', individuals are credited in crowds as rational entity. Conversely, to the past theories this theory reviews the attention from Collective Behavior to Collective Action. This Collective Action depends upon common interest. McPhail's theory aimed at initially on the modus operandi, associated with crowd behavior (1990) (McPhail, 1991). In any revolution crowd behavior changed into collective behavior (Blumer, 1969, pp. 67-121)

\section{SOCIAL MOVEMENTS AND ITS LEVELS}

The four levels of Social Movements have been mentioned. Any movement can be generated at the level of Local, National, Regional, and global.

Local Movement Mostly related to a specific and limited area, concerned with local problems and issues.

National Movement It is the movement has a vast domain throughout the country.

Regional Movement This sort of movement exceeds over different roundabout the countries or one block to another block on the same issue like common interest of business ties.

Global Movement It is an International Movement in which a large number of countries participate in form of alliance. "Slow Food' with the slogan 'Good, Clean, Fair Food' is an international movements spreading with 150 supporters countries (NAACP. 2011).

\section{Sort of Social Movement}

1) Reform Movement: It is for change in a particular social structure.

2) Revolutionary Movement: This movement strives for complete change in every walk of society. "Cuban 26 ${ }^{\text {th }}$, July Movement" under Fidel Castro may be included in the precedence. 
3) Redemption Movement: It means to seek. The goal of movement is instigate the inner change or spiritual development in individuals.

4) Alternative Movement: It focuses on individual development and limited, specific changes in belief and behavior in everyone.

5) Resistance Movement: It is a 'Reactionary Movements'. A group of people supports the status quo and oppose any new change. 'The Ku Klux Klan' and Pro-life Movement are of this kind (Donnally, 2013).

6) In 1970, a new social movement theory appeared which delineates, 'after proliferation of industry, quality of life movements are hard to analyze applying the traditional social theories' (Melucci, 1989).

\section{OBJECTIVE OF THE RESEARCH}

\section{1-To find out the elements behind in bring-up a peaceful social revolution}

2-To investigate how the Pakistani society would be able to bring up a social revolution

3-To Explore what is the factor behind any successful social revolution?

4-To examine whether Pakistani nations can become a social and political revolutionary nation through social media or not?

\section{RESEARCH QUESTION}

1-What were the reasons behind previous revolutions which occurred in history?

2-How does a revolt movement get start in any society?

3-What is the factor behind any successful revolution?

4-The purpose of this research paper is to ferret out the dashing elements of possible social revolution in a society as in Pakistan through social media. 
5-Can Pakistani nation emerge as a revolt or anti-Reactionary nation or cannot?

\section{Psychology of Revolution}

Revolution starts when you say no to those who pretend to have control over you, and revolution comes to an end when you embrace a new status quo, new normal weather which is a change.

Causes: There are mammoth details about the causes of a revolt, but there's one common source, that's the frustration which germinates underneath of the surface. It is a sort of storm that cultivates in people's minds, just waiting to get unleashed. The problem is, the unleashing the storm is much easier than getting people to decide on what's to come next.

\section{PROBLEM OF THE STATEMENT}

It's possible for small groups committed to a course to mobilized and change the established social norms in a population. Over the past researches, there have observation in studies of organizational culture and community activism that have tried to estimate the critical size, which is necessary to trigger a tipping point in 'Social Change'.

\section{RESEARCH METHODOLOGY}

This study based on the qualitative research method. The researcher has developed the method in which online communities are created to study how to change the critical mass. Participants have been recruited in the World Wide Web to become a member in an online community. All the participants are given financial incentives to agree on a 'Social Norm' when they got coordinated and established a norm for the entire community then a small committed group of activists to drive for change are incentivized. The research paper emphasized the theory of Critical masses which could exhibits power of 'Social Media'.

\section{LITERATURE REVIEW}

PREVIOUS SUCCESSFUL REVOLUTION 


\section{French Revolution (1789)}

In May 1789, the French Revolution started, as the American Regime was abrogated supporting the Constitutional Monarchy (Andress, 2015). Before the revolution, French State suffered a lot of budget crisis. Due to drastic social change, the French population increased 18 million in 1700 and 26 million in 1789. Food prices increased by $65 \%$ between 1770 to1790 whist wages increased by only $22 \%$ (Livesey, 2001, p.19) .

There were many reasons behind French Revolution: Social, Economic, imposition of over taxes and the tyranny of the monarchy was prevailing everywhere (Andress,2015). The social condition was at the worst level and the people were under severe deplorable conditions. The French people were sick of monarchy system and wanted to get rid of the monarchy (Jourdan, 2007, p.188). In such a time, American Revolution and the theory of French Philosopher, Montesquie (2011), "The Theory of Separation of Power" raised up a hope of rising a savior for slavery band. According to the theory of 'separation of power', there are three organs of state, Administration, Legislation and the Judiciary. Montesquie (2011) infused the soul of the theory; that all the three organs of state should not be in one hand of Authoritarian. These three organs must execute their responsibilities separately and independently. The message and idea spread swiftly and with alacrity among the French Mass, which brought about the major cause of the revolution. The introductory basic chapter of American Constitution also based on this theory of Montesquie (2011). The French people successfully got united with the help of multiple steps flow of communication, people to people contact from all rank and file emerged in mammoth and bloody revolution came into being. At last, the revolution surmounted the target in 1789 by toppled down the old monarchy system from French State. No doubt, the people of France paid the high price of citizens' lives and the assets. The French Revolution keeps the prominent status among all kinds of revolution of history. It is said to be the 'Mother of Revolution' in the history of human being. (Montesquieu, 2011, p.151-52) and (Mazhar-ul-Haq,1973)

\section{The Russian Revolution}


The Russian revolution is a political social and economic movement that broke out in 1917 in the Russian empire. The consequence was the collapse of the Tsar's Dynasty heirs of the Roman emperor which meant the abolition of the absolutist despotic system that prevailed until then the revolution resulted in a communist-led government led by Vladimir Lenin. There were three main causes that motivated the Russian revolution, heavy casualties at war with Germany. The second cause Russian was suffering an acute economic crisis with shortages of food, the population suffering from hunger. The third cause was they have an autocracy system of governance (History.com, 2009, November 9).

\section{The Chinese Revolution}

Chairman Mao, attempt to establish himself as the leader of the communist world by ridding the country of capitalism and its long-standing tradition. After Mao's communist party took power in 1949 (Schram, 2020, December 22). In 1958, Mao launched a national campaign to boost the Chinese economy called the Great Leap Forward. In 1966, Mao shut down china's schools and mobilized students into paramilitary united called red guards. The groups attacked and killed teachers, intellectuals, and eventually ordinary people they suspected of undermining the communist system. Some of the most horrific violence occurred in the rural village in southern China, where revolutionaries were known to practice ritualistic in the name of the revolution. (Milestones,n.d.)

\section{Arab Spring}

The Arab Spring was a series of pro-democracy uprisings that included Tunisia, Yemen, Syria, Libya, Egypt, Bahrain, and other Middle East countries. Some protests were succeeded, some were finished and some protest continues. Arab Spring was started on 18 December 2010. It was begun in Tunisia when twenty six years old Mohamed Bouazizi fired himself in front of a government building after police slapped and humiliate him refusing to hand over his wooden cart. His act was spread in Tunisia through Social Media Which influence People in Tunisia to stand out for their fundamental rights. When Mohamed Ben Bouazizi died on 4th January 2011, Protestants increased to be against their ruler Zine El Abidine who was ruling Tunisia for 25 years and his regime had to step 
down. After 10 days Zine El Abidine Ben Ali resigned from his rule. Then Democracy has developed in Tunisia. It created hope in People of the Middle East to bring Democracy. People in Egypt then protest against their rule Hosni Mubarak who was ruling Egypt for 30 years, Protestants increased against him then Mubarak had to left his seat, and People in Egypt succeed in bringing democracy. On 15 February 2011 Arab spring effect in Libya where people in Libya started a protest against Muammar Al Gadhafi (Encyclopedia Britannica, 2011). The civil war was started in Libya and the USA was also involved in this war sending NATO. On 20th October 2011, Muammar Al Gadhafi was killed. Yemeni President Ali Abdullah Saleh signed the GCC power-transfer deal in which a presidential election was held. Arab Spring was also converted into Saudi Arabia and Iran Conflict. Syria is the most affected country in the Arab Spring. Now it has been victimized civil war. Fawad Gerges Professor of Middle East politics at the London School of Economics said it was a peaceful protest in the beginning but when authority used their power so it became violent where security agencies were involved. President Asad Moved in Military War. Now Syria has become a stage of the war and was not only a war of people and authority but their crisis also a part of other forces including the USA, Russia, Saudi Arabia and Iran (Pearson And IV Sanders 2019, January 23).

\section{Problems of People in Middle East}

$$
\text { - } \quad \text { Increases in cost of foods }
$$

- An Educated growing population want modernization and Democracy Middle East Population include $28 \%$ of People between 15 and 29 years old which are 108 million young People.

- $\quad$ Economic Problem

- $\quad$ Unemployment in MENA (Middle East and North Africa) is $25-30 \%$ which is higher in the world

- In Libya Increasing of foreign Investment Benefited only rulers as there is less benefit for People.

- In Tunisia one third Population able to attend higher education and there is $30 \%$ more education opportunities than jobs

- In Yemen One third Population Suffer from Chronic Hunger 
In Syria Unemployment increased since 1980. $25 \%$ of economy based on the industry and no more increased profit in agriculture for People and few people benefited from Tax wealth. (Daher, 2018).

\section{Iranian Revolution}

Iran Revolution was known as Persia up to 1935. During the period of the Qajar dynasty (1785-1921) it was given political powers to Ulemas and it was restricted to a constitution on King as the constitutional monarchy was developed at the time of World War I.In 1960 Mohammed Reza Shah gave reforms a white revolution which referred to economic reforms, educational reforms included co-education which create a huge controversy in a country and Ulema went against this initiative. Mohammad Reza Shah Modernized Iran and want secularism in Iran. Ayatollah Rohollah Khomeini a religious leader started a campaign against Shah and influenced people that shah was misusing the authority. Protestants were increased day by day. The government in Iran arrested Khomeini and expatriate to Iraq where he lived 14 years. Khomeini continued his campaign in Iran as Saddam Hussian was worried because he did not want his People into the persuasion of Khomeini so Saddam Hussain exile Khomeini from his country. Ayatollah Rohollah Khomeini then went to Paris. In 1975 Political parties were banned by Mohammad Reza Shah. Censor ship was imposed. The Government in Iran published articles against Khomeini which created more hate in People. Shah called the army and Protestors were killed as he imposed martial law in September 1978. In 1979 military became neutral as when Shah left the US for his medical treatment Khomeini returned Iran in 1stFebuary 1979 and charged the country. Then after 15 days, he appointed his PM. On 30th March through Referendum 98\% votes in the favor of Khomeini. Iran became the Islamic Republic and Khomeini became the supreme leader (Hodek, \& Panadero, 2019).

\section{Social Movements in Pakistan}

According to Arif (2020) in his book "Movements for Change" propounds that "Arab Spring" term contains the range of acknowledgement for the ongoing online and offline political uprisings in the Muslim World, that began beyond the geographical boundaries of Middle East. He tells how 
Al Jazeera used contents of social media of the protesters making to boost the uprisings for an international colloquy. Furthermore, he identifies five social movements in Pakistan (Parvaz, 2014, February 11).

\section{Revolution of Social Media}

Since a successful Social Media Summit was held in Karachi, a large number of people have heed up to the bloggers, the Twitter and the Facebook that made the people an addicts of these. The Egyptian blogger, Mohammed El Dahshan who attended the summit told the audience that how he played leading role through the social media in recent Egyptian Revolution. He is of the view that it can be calculated about a country like Pakistan, Facebook, Twitter, and the Blogosphere users can lead the street to drastic change in Pakistani society (Words.pk, 2018, May 14).

William Martin wrote at the first ever international social media summit that it is a big success, because the participants were full of energy and creative mind set (Martin, 2011, June 11). The top bloggers, Twitter users and others site network gathered throughout Pakistan and some foreign guests also participated belonged to Malaysia, Egypt, Indonesia and America. Undoubtedly, social media have created a Global Village. William Martin was flabbergasted to see the talent, imagination, commitments of the young bloggers. He said, he was ignorant of such a lively and active blogging community more than 3 Million citizen and the journalists are reporting at carte blanche on every topic. The strata of Facebook and Twitter users in Pakistan have been increasing at a gallop since short span of time (Martin, 2011, June 11)

\section{Most Visited Social Media Sites in Pakistan}

There are four top social networking sites in Pakistan. According to Zeb (2017, June 4), the use of internet has been growing with alacrity, since the package of $3 \mathrm{G}$ and $4 \mathrm{G}$ up started in Pakistan. In 2016, the internet usage uplifted to $17.8 \%$, while in 2013 , it was just $7 \%$ and in 2013 was just $10.9 \%$. The statistics of 2016 shows, there were 34.3 million users which have been increasing with every passage of time. 
1.Facebook: this is the number one platform in Pakistan but around the globe Google.com, Google.com .pk and Youtube superceded to the facebook and placed internationally at number four.

2.LinkedIn: this is second most visited site as social platform in Pakistan.

3.Instagram: it is the third most visited social network site in Pakistan.

4.Twitter: this social net work site has come at number four, prior to this, twitter came after Instagram. (Zeb,2017, June 4).

Social Media is a set of websites and applications among them most popular are Facebook, Instagram, Twittter, IMO, Snapchat, Kik and many others. The most important and powerful effective social networking websites are to bring at juxtapose to the people at large under the umbrella of social media clique and platform for attaining a particular objectives. Up till 28 Feb, 2020, the total number of vibrant users of social media in Pakistan, have reached at 37 Million, it means $17 \%$ of the population. Between April, 2019 to January, 2020, 7\% users increased, that means 2.4 Million users increased just in 9 months while mobile users vividly seen 99\% because we find hardly any without a mobile phone (Anjum, 2020, February 26).

\section{Historical Background of Revolution In Pakistan And The Revolution Of Social Networking Sites And Their Impacts}

Field Marshal Mohammad Ayub Khan wrote in his book, "Friends Not Masters" that "A revolution has taken place. You (Iskander Mirza) have ushered it in and you have made me responsible for running the country. It is not just an ordinary routine Revolution, there is going to be a real basic change in this country" (Panhwar, 2018, p,70).

The 1968 Movement in Pakistan. It was very first organized agitation against the dictatorial government of Ayub Khan. The mass agitation turned into mass uprising early in November, 1968. The students, workers and all from every walk of life around ten to fifteen million people got 
involved. Consequently, the Ayub Khan regime had to bring down from the presidency in March 1969. Ayub Khan seized the state power through a coup in 1958. On $21^{\text {st }}$ April,1968, the then Chief Economic Planning Commission, Dr.Mahbob ul Haq, revealed about 22 richest families in Pakistan who controlled $66 \%$ of the industries and owned $87 \%$ in the banking insurance industries.

In early 1968, Ayub Khan celebrated "Decade of Development", which outraged the citizen and mass agitation broke out. A prominent writer, Tariq Ali delineates the story in the following version: The police fired directly at peaceful protester, resulting one bullet hit a first year student Abdul Hamid who died on the spot. this incident enraged the students and replied the police with bricks and paving stones. In February and March 1968 a series of strikes started in the country. In early 1969, in this movement a total of 239 people were killed, 196 in East Pakistan and 43 in West Pakistan., most of them were students (Mansoor, 2018, December $31)$.

Aftermath: Ultimately, on $25^{\text {th }}$ March, 1969 Ayub Khan had to resigned as a president of Pakistan because of mass uprising from students and every walk of life.

Undoubtedly, uprising in the then East Pakistan, 1969, was a democratic political movement. The uprising also led to withdrawal of Agartala Conspiracdy Case and acquitted Shiekh Mujibur Rehman and the companion.

\section{Bangladesh Libration War or A Revolution in East Pakistan}

Bangladesh got an independence on $16^{\text {th }}$ December,1971 from the West Pakistan rulers.

According to historical background, it is said that Pakistan Army began an "operation Searchlight" in the mid-night may be around 11.p.m on $25^{\text {th }}$ March 1071. The purpose of this operation was to stop the legal demands of Bengalis to be allowed them to form the federal government of Pakistan because Awami League, the political party of East Pakistan had won the 
general election under the leadership of Sheikh Mujibur Rehman who had obtained the fresh majority in the election to form the central government.

A blame is put on the Pakistan Army that they prepared the death squads roaming in the streets of Dhaka, killed more or less 7000 people, mostly of them were civilians, university students and partially some unarmed police and EPR soldiers. In a single night and a week fifty percent of Dhaka population had run away to save their lives. It is said, at least 30,000 people were killed in Dhaka city only (Wikipedia n.d.).

It is said Bengali nation were treated as second rate citizen by the then rulers and the military establishment of west Pakistan. The real bone of contention started at six points agenda put forwarded by Sheikh Mujibur Rehman, which was not acceptable by the rulers of West Pakistan at all because it was sheer separation of two parts physically. The Awami League demanded changes in East Pakistan which were presented at meeting of opposition parties in Lahore in 1066. The glimpses of six points are as given below which caused revolt in East Pakistan.

1. The constitution should provide for a Federation of Pakistan in its true sense based on the Lahore Resolution.

2. The federal government should deal with only two subjects: Defense and Foreign Affairs only.

3. Two separate, but freely convertible currencies for two wings should be introduced.

4. The power of taxation and revenue collection should be vested in the federating units.

5. There should be two separate accounts for the foreign exchange earnings of the two wings.

6. East Pakistan should have a separate militia or paramilitary force. 
It was unequivocal to turn down the demands of Awami League because accepting the demands means depriving from the East wing. Thereafter, the Bengali nation become averted and stood towards revolt. In the views of Bengali nation it is a political revolution but the rulers and military establishment called it a mutiny same as we called war of independence 1857 but English called it a mutiny.

In 1977 general election PPP of Zulfiqar Ali Bhutto won the election but Pakistan National Alliance accused of rigging in general election (Talbot, 2009). A social unrest and political conflict started between leftist ruling party and right-wing Islamist opposition parties. A mass agitation enraged the country. There were several meetings between opposition and ruling parties' delegation but no result come out. In the meantime, the then chief of Army Staff Zia ul Haq launched a coup with the name of "Operation Fair Play" (Ali, 2018, August 17). So the change of government and system came into being on the mass agitation of people of Pakistan. Although it was a dictatorial government, yet people also wished for that. In other words, it can be said because of people agitation military intervention become inevitable in that situation. It cannot be regarded as revolution but on the wish of people demand it came as revolution. According to Talbot (2009), "The reality seems to be that a certain PPP victory was inflated by malpractice committed by local officials, which may have affected $30-40$ seats."

\section{Lawyers Movement of Pakistan (2007 to 2009)}

According to Phelps (2009) Iftakhar Chaudhry became the Chief Justice of Pakistan's Supreme Court in 2005. The way the court led by the Chief Justice was embarrassing for the then President Pervez Musherraf because he challenged the legality of Musherraf as a president and as a Army Chief. On $9^{\text {th }}$ March,2007 Pervez Musherraf sacked Iftikhar Chaudhry from the post on the charge that he was misusing the his authority. After that a storm of agitation from lawyers staged and a movement called "save the Judiciary Movement" (Adliya Bachao Tehreek) started. About 80,000 lawyers gathered across the country to reinstate the chief justice.

On $3^{\text {rd }}$ November, 2007, President Musherraf declared a state of emergency in the country and along with enacted a Provisional 
Constitutional Order. The lawyers to staged demonstration all over the country become more organized. (Rohde, 2007, November 3). When Musherraf declared state of emergency rule, the lawyers executing their duties as usual in an act of defiance. ASindh high court lawyer, Kashif Paracha delineates that police were found busy in arresting the lawyers from everywhere. Police searched thoroughly in the library, in the canteen without doing any thing wrong on the part of the lawyers. In crack down at Sindh High Court and there around, it is estimated more or less twentyfive thousand lawyers and political workers were arrested to muffled the voice being to be raised in the demonstrations. This lawyers movement not only got full support from politicians and civil society but from international high officials. Iftikhar Chaudhry himself wrote some letters to the official of America and Great Britain. Ultimately, these two countries who had been supporting him as ally of combating terrorism, later, appealed to abrogate emergency order in the country. On 11 June, 2008, decided to launch a long march demanding resignation of Pervez Musherraf and reinstatement of deposed judge Iftikhar Chaudhry (Siddique, 2008, June 11). The members of vast variety of civil society and political supporters joined the long march. On $18^{\text {th }}$ August,2008, Musherraf resigned as president due to mass opposition and fearing impeachment. Hence the lawyers movement reached at its destination and achieved the target.

According to Kugelman (2012) "Social media in Pakistan used as a tool of communication in five different ways." Firstly, they rectify and ferret out the stories while traditional media are unable to or not willing to give importance. Secondly, social media provide communications platform on projecting protest and campaign and other social movement that enable mobilizing character. Thirdly, the communication of social media plays a role of humanitarian dimension. They facilitate the process of charitable opportunities and in state of emergency facilitate relief needs, and cooperate and invite the donation as well as donors. Fourthly, Pakistani social media advocates and become partisan for social causes or issues. Finally, the new media resources of Pakistan stimulate in political ways of communication and now all prominent political leadership even ISPR have started using Twitter as their tool of communication with the people at large (Kugelman, 2012). 
An article was published in Daily Times newspaper in 2018 by Daud Khattak, where he talks about revolutions by social media sites in Pakistan. In his article, he talks about the Zainab murder case and the Naqeeb-Ulla-Mehsud encounter. (Khattak, 2018, February 3). During the investigation of the Zainab murder case, the agency has found that the accused person had already done much minor age raped and also women's in his area but the police were unable to found him. The thousands of people including several activates criticizing authorizes and the general lack of security in the area a lot of people are using the Hashtag \#Justiceforzainab. People show their anger towards government \& agency. The pressure of social media work out, the accuser Imran Ali got the death sentence.

\section{Zainab Murder Case}

The controversy that started on January 4th when Zainab got missing and this news was flouting on social media sites but the controversy, after the 5 days later her body is found in trash in Kasur. The Punjab Government announced on the 9th of January that they found the main accuser Imran Ali. He had allegedly confessed to rape and murder of six-year-old Zainab Amin. During the investigation, it was also revealed that he had also murdered another three minor age of girls who were five, six, and eightyear and he had raped another 12 women as well from the same area. On the 12th of June anti-terrorism court finally given a death sentence and he had hanged on the night of 17th October. (Liaquat, 2018, October 17)

\section{Naqeeb-Ulla-Mehsud}

Another case was highlight by social media sites, Naqeeb-Ulla-Mehsud a guy who belongs to Waziristan. This case creates emotional sentiment in Pashtun spoken people and also played important for local politics. Naqeeb-Ulla-Mehsud was killed in a police encounter, which was conducted by encounter specialist Sindh police SSP Malir Rao Anwaar. People who stood-up against Rao Anwaar for fake encounters and all campaign began on social networking sites. When this news became a part of mainstream media than Chief justice of the Supreme Court of Pakistan took notice and this was the breakthrough in this case (Ali, 2018, June 18). 


\section{Shazaib Murder Case}

Another article that was published in The Nation by Muhammad Atif, was he talking about Shazaib Murder case. (Atif, 2013, February 11). Social networking sites always raised their voice against stereotypes. One of the cases was Shazaib's murder, the main accuser was arrested after a few days because of social media pressure. But the system of Pakistani police is giving leverage to the son of feudal person. Shahrukh Jatoi killed Shazaib because he overtakes his car. But this case impacts our society against the feudal system which was always in privileges especially in Pakistan. (Ashafaq, 2019, May 13).

\section{Killings of Innocents at Sahiwal}

A counter Terrorism Department (CTD) stopped the car of family in January,2020, at Sahiwal and killed four people suspecting as terrorists. The deceased were, M.Kahlil, his wife, elder daughter, the driver, Zeshaan. Only the two children, Umair and Muneeba could survived in the foray.

Amazingly CTD team declared innocent and acquitted. The video footage, shot on a Mobile camera by on the way on lookers, disclosed that it was intentional murder. The incident occupied the headlines for weeks and maintained the Twittering message and anger on the official ignorance. Prime Minister Imran Khan was compelled to take notice and said in a Twitter post, he will bring the responsible to book that could pacify the mass anger but later, in September 20, the squad of CTD was released due to insufficient evidence. This weak prosecution of the case once again angered the social media that forced the government to order an inquiry for the negligence in prosecution. All these happened due to power of social media otherwise the perpetrated team of CTD would have been acquitted and would add insult to injury on the system (Centola, Becker, \& Brackbill, 2018, June 8).

\section{Dead Chicken at Baoo Jee Restaurant}

A video went on viral on social media on $18^{\text {th }}$ November, 2019, that a man is unloading dead chicken for delivery to a restaurant. In the video the man 
revealing these chicken are being supplied to Baoo Jee Restaurant. Assistant Commissioner Islamabad with food authorities raided the restaurant located at Khanna Bridge, Islamabd (Baoo, 2019, November 20). A huge quantity of dead chicken was recovered by the raid team. Hence the video on social media saved the customers to come for eating the dead chicken pallao.

\section{Motor Way Gang Rape Case}

in September,2020, this incidence happened at Motor Way, when a woman with her children was going to her destiny but unfortunately the fuel got consumed all on the way. The car was halt and she was waiting for some help from the passer by. In the mean time, taking advantage of the deserted point the crime perpetrators hunted the woman before her children for rape. The news caught like jungle fire on the social media. At first, Punjab police chief said in ridiculous manner that why the woman had come out in night? Adding insult to injury the Faisal Wada and some other minister tried to defend and put off the fire. On such a irresponsible statements and indifferent attitude of the concerned authority, the social media ignited the conflagration on the issue that compelled administration and the police to arrest the accused at any rate. According to Daily Dawn, $13^{\text {th }}$ October,2020, published the headline "Main Suspect in Motorway gang -rape case arrested form Faisalabad. On the hectic arrest of Abid Ali, Dr. Shahaz Gill PTI, Twittered," Abid Ali has been arrested, if God will he will be punished according to law". Similarly, the President of Pakistan Dr. Arif Alvi Twittered on $12^{\text {th }}$ October,2020, “Arrest of the $2^{\text {nd }}$ motorway accused rapist is a matter of national relief. An efficient trial of the accused and the 'severest exemplary' punishment possible under the law must be given to all those found guilty. Let everyone feel safe in Pakistan, especially our women and children.

\section{Revolution in Pakistan: Might Be Possible in Future}

In our research paper, we have explained that what the psyche of revolution is. Our research paper shows that the elements need to bring-up a revolution in society. The social media of Pakistan has been vibrant and bears all great potential that needs to foster a revolution in future. At present, undoubtedly, the social media of Pakistan cannot bring up a 
revolution in short span of time. The fact is that the social media and the users both are teenagers. A certain time is quite possible for a revolution. Time has to be give to both such that they could reach at level of required maturity for reaction force. According to Martin (2011, June 11) and Kugelman (2012), "they have witnessed the great energy and potentials among the users". The social media of Pakistan already had began mobilization the people as we have studied about many movement and the admonishing voice of the social media over any cruelty, heinous crime and any injustices in Pakistan. Social media have achieved maximum out comes on many social issues as mentioned earlier about many murder and rape cases.

Secondly, it is due to our social media and cable channels that people of Pakistan have began to realizing, who are ruling over them. Mostly, the political leadership all are advanced level corrupted and some families time and again rule the country alternatively. Since the independence 1947, the major period of the rulers comprising either military regime or family's government. They have taken to grant the people of Pakistan as their subject and they are their masters. This is the public contention about the rulers which is vital for a revolution because the same concept had been living in all those revolutions where revolution took place successfully.

For a successful revolution two major elements have great correlation. Firstly, an objective of common interest or goal for the people at large. Secondly, a leader having ability of far-sighted and a man of integrity like Nelson Mendela, Quid-e-Azam. At present, the people of Pakistan have a common goal to acquire true democratic system with its true spirit without holding or influence of feudal lords or leaders of family politics. The people of Pakistan have been sick of all the old trumpery faces, who have been running the country their own will rather on the will of the people. Imran adapted the slogan for 'change', the people had great expectation from him so supported cordially all over Pakistan, as the nation has been sick of old faces. Imran Khan and his Party PTI won the seat from Lyari and from Nine Zero amazingly. It shows that people can change their traditional support for the change, if alternate choice be available to people. If a leader of integrity come forward for the change of system social media has the capability to mobilize the people towards the 
revolution. But unfortunately, Imran Khan disappointed the nation in the name of change. It means unequivocally, Pakistani people have common goal for changing the rotten system. But there is no leader on whom the nation could put trust on him. The nation lying awaiting for a leader of integrity, as and when someone ignite the ray of hope, revolution will get start itself through social media.

\section{FINDINGS}

We have explained in the context of Pakistani society, the phenomena of revolution at present looks non-operational in a country like Pakistan where people have divided themselves into classes and subclass, liberals and conservative, libertarian, socialists, democratic, religious, sect., provisional difference, language and more but all of these elements, we have found that people of Pakistan are "cathartic people" they can aggrandize their aggressive emotions by watching current affairs news shows. Moreover, the literature review also suggests that Pakistanis having the liberty to express their anger through platforms of social media which is paving the way of revolution to come in long future.

According to Kugelman (2012) the social media in Pakistan has been an important forum for communication. The Pakistani media imparts its services as propagator of information, as an agent of mobilization for protesters, as helper for humanitarianism, an advocacy for social causes, and a bridge between the government and the people for political dialogue. No doubt there is factual account in respect of environment and having limited accessibility. At present, obviously Pakistani media not looks an agent of change but it does not mean that the political and social condition of masses and media will remain the same. Pakistani media acquiring the status of catalyst for change slowly but persistently. Because the number of social media users are increasing at a gallop speed with the passage of time. Social media of Pakistan have raised the crying and admonishing voices on any injustice done in the society with any one, it shows, the smoking signal are lying beneath the social circle. One spark on national issue can change the scenario for the change (Farooq, 2019, February 6). Pakistani media can step forward towards reaching the mile stone of revolution, just time be given for appearing a leader of integrity and let the social media and the mammoth users be matured. 
As the social media of Pakistan is getting gigantic figure of communication to put on social effects, so, it can infuse a revolutionary spirit amongst the masses, because the people of Pakistan have great potential to react emotionally and aggressively. Therefore, a revolution in future might be possible and activated through social media in Pakistan.

\section{CONCLUSION}

In conclusion, we have found that all the ingratiate needs to start a revolution are there in the demography of Pakistan. Although as a nation we are divided into many forms, yet the smoking signal very exit there in Pakistani society. For Revolution unity is the basic lever, which is found in our society as William Maritn also indicated in the Karachi social media summit. Pakistan has a versatile society having great potential for change. We have perceived that people of Pakistan manage to express their feeling towards any issues through mainstream media and social media platforms. Another thing that is needed to start a revolution is leadership. No doubt, Pakistani has a leadership crisis. People of Pakistan are lying awaiting for a single leader, who could gather the people on a single agenda of change. Our previous revolutions case study says that most of the countries have autocracy, the same is the case with Pakistan, where in the name of democracy families or dictators have been running the state affairs. Pakistan demography has a democratic system; people seeking and desiring for the true democracy, that is "government of the people, by the people, and for the people". 


\section{REFERENCE}

Ali, I. (2018, June 18). Anger on social media after Waziristan man killed in Karachi 'encounter'. Daily Dawn. https://www.dawn.com/news/1383540

Ali, Z. (2018, August 17). The Political Influence Of Pakistan's Powerful Army. BBC News. https://www.bbc.com/news/av/world-asia$\underline{45225923 .}$.

Andress, D. (2015). The Oxford Handbook of the French Revolution. Oxford University Press,

Anjum, U. (2020, February 26). Internet penetration in Pakistan as of 2020. PhoneWorld. https://www.phoneworld.com.pk/internetusers-in-pakistan-2020/

Arif, R. (2020). Movements for change: How individuals, social media and Al Jazeera are changing Pakistan, Egypt and Tunisia. Peter Lang, International Academic Publishers.

Ashafaq, A. (2019, May 13). Shahzeb Khan's murder was shocking but was it 'terrorism'? The Nation. https://nation.com.pk/11-Sep2013/shahzeb-case-closedhttps://www.dawn.com/news/1382041

Atif, M. (2013, February 11). The role of social media in changing future of Pakistan. The Nation. https://nation.com.pk/11-Feb-2013/therole-of-social-media-in-changing-future-of-pakistan

Baoo, J. (2019, November 20). Video: Is Islamabad's famous “Baoo Gee Murgh Palao" using meat of dead chickens? Siasat.pk News Blog. https://blog.siasat.pk/video-is-islamabads-famous-baoo-geemurgh-palao-using-meat-of-dead-chickens/

Blumer, H. (1969). Collective Behavior. In Principles of Sociology, edited by A.M. Lee. New York: Barnes and Noble. 
Centola, D., Becker, J., \& Brackbill, D. (2018, June 8). Experimental Evidence for tipping points in social convention. Science 360(6393), 116-1119. https://science.sciencemag.org/content/360/6393/1116

Daher, J. (2018). The Political Economic Context of Syria's reconstruction: a prospective in light of a legacy of unequal development. Robert Shuman Centre for Advance studies. European University institute. https://cadmus.eui.eu/bitstream/handle/1814/60112/MED_2018_0 5.pdf?sequence $=4$

Donnally, J. (2013). The Politics of Abortion and the Rise of the New Right. (Unpublished Doctoral Dissertation) University of North Carolina at Chapel Hill https://core.ac.uk/download/pdf/210603225.pdf

Encyclopedia Britannica, (2011). Libya Revolt of 2011. https://www.britannica.com/event/Libya-Revolt-of-2011

Farooq, M. (2019, February 6). Active social media users in Pakistan grow by 5.7\%: Report. Profit by Pakistan Today. https://profit.pakistantoday.com.pk/2019/02/05/active-socialmedia-users-in-pakistan-grow-by-5-7-report/

History.com Editors. (2009, November 9). Russian Revolution. HISTORY. https://www.history.com/topics/russia/russianrevolution

Hodek, J., \& Panadero, M. (2019). Iran Strategic Report. GLOBAL AFFAIRS.

https://www.unav.edu/documents/16800098/17755721/IranStrategic-Report_MEscudero-JHodek_09_09.pdf

Jourdan, A. (2007). The Alien Origins of the French Revolution: American, Scottish, Genevan, and Dutch Influences. University of Michigan Library 
Khattak, D. (2018, February 3). The power of Social media. Daily Times. Karachi https://dailytimes.com.pk/194285/power-social-media/

Kugelman, M. (2012). Social Media in Pakistan: Catalyst for Communication, not Change. Oslo: Norwegian Peace building Resource Centre.

Liaquat, N. (2018, October 17). Zainab's rapist, murderer Imran Ali hanged at KotLakhpat Jail. Daily Dawn. https://www.dawn.com/news/1439400

Livesey, J. (2001). Making Democracy in the French Revolution. Harvard University Press.

Mansoor, H. (2018, December 31). Anti-Ayub movement of 1968 remembered. Daily Dawn. https://www.dawn.com/news/1454507.

Martin, W. (2011, June 11). Pakistan's Social Media Revolution. Express News. https://tribune.com.pk/story/186962/pakistans-socialmedia-revolution

Mazhar-ul-Haq. (1973). Principles of Political Science. Lahore: Bookland.

McPhail, C. (1991). The Myth of the Madding Crowd. New York: Aldine de Gruyter.

Melucci, A. (1989). Nomads of the Present. Philadelphia: Temple University Press

Montesquieu, C. B. (2011). The Spirit of Laws. Cosimo.

NAACP. (2011). 100 Years of History. National Association for the Advancement of Coloured People.

http://www.naacp.org/pages/naacp-history.

Panhwar, S. H. (2018). A Friend not Master: A Political Auto Biography by Mohmmad Ayub Khan. 1967. http://www.sanipanhwar.com/Friends-Not-Masters- 
A\%20Political\%20Autobiography\%20by-President\%20AyubKhan-.pdf

Parvaz, D. (2014, February 11). Iran 1979: The Islamic revolution that shook the world. Al Jazeera. https://www.aljazeera.com/indepth/features/2014/01/iran-1979revolution-shook-world-2014121134227652609.html

Pearson, A. And IV Sanders, L (2019, January 23). Syria conflict: What do the US, Russia, Turkey and Iran want? DW News. https://www.dw.com/en/syria-conflict-what-do-the-us-russiaturkey-and-iran-want/a-41211604

Phelps, J. (2009). Pakistan's Lawyers Movement (2007-2009). International Center on Nonviolent Conflict. https://www.nonviolent-conflict.org/pakistans-lawyersmovement-2007-2009/.

Rohde, D. (2007, November 3). Musharraf Declares State of Emergency. The NewYork Times. https://www.nytimes.com/2007/11/03/world/asia/04pakistan.html.

Schram, S R. (2020, December 22) Mao Zedong: Chinese leader. Encyclopedia Britannica. https://www.britannica.com/biography/Mao-Zedong

Shah, A. (2020, January 23). How Pakistan's Politicians Help the Military. The New York Time, https://www.nytimes.com/2020/01/23/opinion/pakistanpoliticians-military.html

Sharp, G. (2012). From Dictator to democracy: A Conceptual Framework of Liberation. New York: News Press.

Siddique, A. (2008, June 11). Pakistan: Lawyers' 'Long March' Heads Toward Islamabad. Radio Free Europe, Radio Liberty. https://www.rferl.org/a/1144599.html 
Talbot, I. (2009). Pakistan: A modern history. Hurst.

Wikipedia (n.d.). Bangladesh Liberation War. https://en.wikipedia.org/wiki/Bangladesh_Liberation_War

Words.pk (2018, May 14). Power of Social Media in Pakistan. https://words.pk/power-of-social-media-in-Pakistan/

Zaheer, L. (2018). New media technologies and youth in Pakistan. Journal of the Research of Pakistan, 55(1), 107-114. http://pu.edu.pk/images/journal/history/PDFFILES/8_55_1_18.pdf.

Zeb, Y. (2017, June 4). Which Social Media Site is most visited in Pakistan: Top 4 social networks in Pakistan Research Snipers News. https://www.researchsnipers.com/social-media-site-visitedpakistan-top-4-social-networks-pakistan/ 